DOI: https://doi.org/10.34069/AI/2021.39.03.14

\title{
Forms of committing corrupt abuses of public finances and ways to counteract them in Ukraine
}

\author{
Форми вчинення корупційних зловживань з публічними фінансами та способи \\ протидії їм в Україні
}

Received: April 5, 2021
Accepted: May 4, 2021

Written by:

Volodymyr Sukhonos ${ }^{48}$

https://orcid.org/0000-0002-9058-5182

Ludmila Pavlenko ${ }^{49}$

https://orcid.org/0000-0002-4724-7567

Olena Krukhmal ${ }^{50}$

https://orcid.org/0000-0001-9118-1713

Alla Ivanovska ${ }^{51}$

https://orcid.org/0000-0001-8608-5030

Dmytro Maletov ${ }^{52}$

https://orcid.org/0000-0002-1241-1005

\section{Анотація}

Метою статті $€$ детальний та комплексний аналіз форм вчинення корупційних кримінальних зловживань, предметом яких $є$ публічні фінанси. Об'єктом дослідження є суспільні відносини у сфері функціонування публічних фінансів та забезпечення фінансової безпеки. Автори наголошують на важливості даного дослідження для побудови стабільної економіки в державі та протидії фінансовим загрозам. У статті проаналізовано різноманітні визначення щодо сутності фінансів та публічних фінансів. Для досягнення поставленої мети у статі було застосовано комплекс методів: логічний, метод документального аналізу, логіко-семантичний, системно-структурний, формально-юридичний та інші. Авторами виокремлено та детально проаналізовано форми корупційних зловживань, предметом яких $\epsilon$ публічні фінанси: зловживання у сфері публічних закупівель, відмивання доходів у сфері публічних фінансів та привласнення, розтрата та заволодіння публічними фінансами, зловживаючи службовим становищем. А також

\footnotetext{
48 Doctor of Juridical Sciences, Professor, Department of Fundamental Jurisprudence and Constitutional Law, Sumy State University, Ukraine.

${ }^{49} \mathrm{PhD}$ in Economics, Associate Professor, Senior Lecturer, Department of Finance, Banking and Insurance, Sumy State University, Ukraine.

${ }^{50} \mathrm{PhD}$ in Economics, Associate Professor, Senior Lecturer, Department of Finance, Banking and Insurance, Sumy State University, Ukraine.

${ }^{51} \mathrm{PhD}$ in Law, Professor of the Department of Constitutional, Administrative and Financial Law, Leonid Yuzkov Khmelnytskyi University of Management and Law, Ukraine.

52 PhD student, Department of Administrative, Economic Law and Financial and Economic Security, Sumy State University, Ukraine.
} 
the financial well-being of the population and create a negative image on the international stage. Taking into account the level of legislative regulation, legal awareness, legal culture and education of the population of Ukraine was proposed to combat corruption in two main areas.

Keywords: corruption, corruption criminal offencesformsofcorruptabuses, publicfinances, ways to counteractcorrupt abuses. запропоновано два напрями протидії означеним формамп орушень: загальний та спеціальний. У межах яких виділено окремі дієві способи. Робиться висновок, що зважаючи на демократичні та правові прагнення України, нині ця держава все ж належить до найбільш корумпованим. Особливо згубними є зловживання у сфері публічних фінансів, адже вони знижують економічний потенціал держави, фінансовий добробут населення та створюють негативний імідж дляУкраїни на міжнародній арені. Пропонується, зважаючи на рівень законодавчого врегулювання, правової свідомості, правової культури та освіченості населення України здійснювати протидію корупційним зловживанням за двома основним инапрямами.

Ключовіслова: корупція, публічні фінанси, форми корупційних зловживань, способи протидії корупційним зловживанням, корупційні кримінальні правопорушення.

\section{Introduction}

According to the Basic Law, Ukraine is a democratic and legal state, where the rule of law prevails. Unfortunately, this constitutional provision is most likely purely declarative and reflects the aspirations and hopes of our country. After all, despite numerous institutional, legal, economic, and political reforms, the level of corruption remains catastrophic. In the minds of citizens for centuries formed a neutral or even favorable attitude to corruption, ie socio-moral phenomenon that can not exist separately from people - their behavior, activities (Akimov, 2014). During the existence of the Russian Empire, bribes and gifts were sometimes the only way to feed officials, as they did not receive an official fixed salary at all. Such historical features have formed and ingrained in the minds of citizens an acceptable attitude to corruption (Bondarenko, Reznik, Yevgen, Andriichenko, \&Stohova, 2020). This is confirmed by the Transparency International rating, according to which Ukraine received 33 points in 2020 according to the Corruption Perceptions Index and took 117 th place out of 180 countries on the list. Corruption permeates all spheres of society, at the same time one of the most pernicious is corruption in the field of public finances, because it negatively affects economic features (Shrabani \& Kunal, 2021), and its subject is mostly funds in significant amounts. Moreover, corruption is detrimental to economic growth by reducing investment in both physical and human capital (Knack \& Keefer, 1997). Today in Ukraine, corruption is a way of thinking that determines the way of life of people involved in the distribution of public finances. After all, in reality, every stage of the movement of financial resources in the public sector and the sectors that interact with it can create conditions for corruption schemes. Thus, corruption can manifest itself not only in the stages of budget execution. It can be in attendance with the whole process from the moment of formation of the program document in the form of the state budget for each year, its approval in the Verkhovna Rada, its further execution through payment of taxes and obligatory payments, and functioning of revenue bodies to the moment of its actual execution, taking into account public procurement process (Shkolnyk \& Savchenko, 2018). The above determines the relevance and importance of the author's study

\section{Theoretical Framework}

On the whole, the term "finance" is both an economic and legal category, ie a basic concept used by both economics and law. The term "finance" can be considered as a process in which economic relations arise over the formation and expenditure of funds. Public finances and their economic relations are characterized by the formation and use of funds solely for public purposes, pursuing the public interest. In our opinion, such a feature as the public interest is fundamental and determines 
other characteristics of public finance, primarily: the formation and use of public law entities, specialization of legal regulation with the establishment of certain special rules of use, and implementation of public financial control.

A basic premise for the progressive development of any state is the efficient use of financial resources. The creation of a self-sustaining financial system is a core function of management actions of state and local authorities and is achieved through effective management of public finances. Public finance management should ensure the formation and distribution of public centralized and decentralized funds, which are necessary for the state and local governments to perform their functions. To substantiate the approaches based on which it is possible to analyze the effective management of public finances and the formation of measures to combat their abuse, we must first determine the essence of this concept, considering the approaches of scholars to its interpretation.

The most general definition gives L. Focsha. The system of public finance is presented as a set of centralized and decentralized funds, which are closely interrelated while maintaining relative independence (Focsha, 2014). There may be doubts about the validity of this definition, as there are public funds that are not subject to public administration.

The generalized interpretation gives also $\mathbf{M}$. Carlin, who understands public finances as a set of state and local finances because the population at the state or local levels (Carlin, 2015) shares them. In the author's opinion, this definition provides a too oversimplified conception of public finances, as it does not take omit the management aspects that must be present in the process of formation, distribution, and use of public finances.

D. Bös brings to a sharper focus public finances, dividing them into public finances of the state, local governments public finances, and public finances for public purposes (Bös, 2003).

L. S. Winer notes that "public finances are financial funds formed by financial relations, which are necessary for the existence of public bodies and the financing of their functions" (Winer, 2002).

Research and regulatory framework digest suggest that there is no common comprehension of the essence and composition of public finances in information sources. This makes it impossible to effectively manage them and creates problems in the process of real distribution and draft of public funds.

However, it is not only the ambiguous interpretation of the essence of public finances that is a problem. In Ukraine, there is a situation where corruption, inadequate provision of social services to the population, and inefficient governance result in non-transparent use of public finances. It is worth mentioning the fact that in 2009-2020 the public finance deficit increased from UAH 26 billion to UAH 169 billion, which led to a spiraling increase in the debt burden, because the larger and more expensive the debt, the more new debts have to be attracted. In turn, this slows down the development of the Ukrainian economy (Taran, 2016).

In general, the analysis of public financial management in Ukraine allows us to identify the following main problems that exist in this area:

- $\quad$ significant absence of pattern and unclear legal framework allows officials and other entities responsible for the reassignment of public funds to abuse in the process of performing their duties and powers;

- $\quad$ there is no single space of administrative and legal regulation of public finance management in the country;

- budget administration as an important aspect of the drafts on budget funds requires clear regulation at the legislative level;

- the rules that determine the procedures for the allocation and reassignment of financial resources often need to be improved and brought into line with modern requirements and European integration aspirations of Ukraine.

Thus, based on the above and supporting the above definitions of public finance, it is possible to give the following definition: public finance a system of economic relations arising in the process of formation, distribution, and use of funds needed to perform tasks and functions of the state, local government, other funds designated by the state as public and necessary to meet and meet public needs, as well as related to the control over the effective and targeted use of these funds. 


\section{Methodology}

To achieve this goal, a set of methods was used in the article. Peculiarities of the research structure are determined by a combination of legal and economic methods that make it possible to achieve its goal. The logical method allowed, based on the study of statistical literature, to describe in detail and systematically the nature and types of corruption abuses in public finance. Under the effect of the method of documentary analysis, it has become possible to analyze documents on the essence of corruption forms in the field of public finance. Using the logicalsemantic method, the authors were able to analyze in detail the essence of the scientific concept of "public finance". Subsequently, these definitions were generalized and improved, which allowed to develop the author's concept of "public finance". However, the system-structural method helped to explore the essence of ways to combat corruption offenses, the subject of which was public finance. The formal-legal method and the forecasting method made it possible to clarify and single out the prospects for improving the fight against corruption in the field of public finance. We also used a scenario method that allowed us to develop our own ways to combat corrupt abuses in public finance. Several other general and special methods of scientific knowledge were used in the work, which allowed a thorough and comprehensive approach to the implementation of our study.

\section{Results and Discussion}

\section{Forms of corrupt abuses of public finances}

\section{Abuses in the field of public procurement}

Public procurement, which is a mandatory component of the functioning of the state and local authorities, entails several risks associated with a high probability of financial abuse in this area; the latter result in losses both for the state and territorial communities and for potential participants of the procurement system, negatively affect the image of our country, lead to despair and disappointment of the population, the decline of the authority of government (Yushko, 2018).

In Ukraine, there is an electronic public procurement system Prozorro, which is an online platform where state and municipal customers announce tenders for the purchase of goods, works, and services, and business representatives compete in tenders for the opportunity to supply it to the state. Hundreds to tens of thousands of procurements take place every day in the Prozorro system. Most of them are purchases of state customers, which are financed from the state budget, ie belong to public finances. This can be buying food at school or repairing a road of international importance. Information on all purchases can be found on the Prozorro website. Unfortunately, even the most transparent public procurement system does not guarantee 100\% protection against abuse. So different types of corruption abuses are possible:

1) the contract placed in the Prozorro system has not been performed, has not been performed in full or of poor quality;

2) the winner in the competitive bidding is the person not with the most advantageous offer;

3) conspiracy in the tender for the repair of the yard participated only two participants: the company of the person living there and the company of his wife;

4) incorrect procedure (for example, the Department of Housing and Communal Services purchased the repair of the yard under the procedure COVID-19. Of course, this is unacceptable, because the repair is not exactly included in the list of what can be purchased under this procedure) (Ferenc, 2020).

Abuses in the conduct of competitive auctions begin from the moment of providing information about the auction and preparation of tender documents. As a purse, the customer receives a "kickback" from their winner. The number of such kickbacks, which are ultimately carried out at the expense of public finances, can be up to $50 \%$ of the value of the subject of procurement. It is clear that because of such auctions, procurement is carried out at overcharge prices. Significant offenses in public procurement also occur as participants in tenders. The most common of these is a conspiracy between procurement parties to gain an advantage over one of them. The essence of such conspiracies is that competitors agree before bidding on who will present the "best" offer to obtain a contract. Sometimes potential bidders refrain from submitting bids at all, but more often they submit bids with deliberately inflated prices or underestimated quality indicators. The winner of the tender determined in this way is then settled with the participants of the conspiracy by the share of the received profit indirect (cash) or indirect (subcontracts, mutual settlements) form (Melnikov, 2016).

At the stage of payment and control of the contract, there may be a risk of corruption in the 
form of an attempt to negotiate the terms of the contract after the winner has been determined, but before it was signed. The Law on Public Procurement strictly prohibits negotiations after a proposal is submitted. Exceptions to this rule apply only in cases where the chosen procurement procedure allows for dialogue between the customer and the tenderer (eg a negotiated procedure). All decisions must be documented, including an evaluation report containing the results of the evaluation of participants in tenderers and tender offers. If this is not the case, manipulations are possible in assessing compliance with the criteria, as well as technical requirements. As a result, a conspiracy between a corrupt company and a corrupt official leads to higher prices due to changes to the contract. Subcontractors may be selected opaquely and will not be held accountable for their work (Altsyvanovych, 2018).

\section{Legalization of income in the field of public finance}

The financial security of all spheres of public life directly depends on the optimally functioning financial system of the country, which, in turn, is a direct reflection of the level of economic development of the state as a whole. In Ukraine today, the formation of an independent national financial system continues by reforming the financial system that existed in our country before the declaration of independence. This is because its formation and development is a rather complex process (Utkina, 2016). The situation with reform is complicated by the fact that one of the most important global problems facing society as a whole is the financial system in particular is the control of cash flows, as well as the fight, counteraction, and prevention of money laundering. In particular, the process of laundering such revenues poses an extreme threat not only to the financial but also to the national system as a whole (Utkina, 2020). The main problem is that money laundering weakens the integrity of financial systems, leads to loss of control over the country's economic policy, distorts the economy, causes instability of investment, and leads to reduced tax revenues for the government (Chen \& Siems, 2004). The problem of money legalization or other property obtained by criminal means is of special importance for Ukraine, as the criminalization of the economy is a major threat to the economic security of the state (Shulga, Perepelytsia, Duravkin \& Sharenko, 2019). The analyzed criminal offense is characterized by high social danger, as it is a kind of stage of criminal activity and is often associated with corruption, contributes to its formation, financing, and progress; may adversely affect property ownership; financial and credit system, justice (Reznik \& Bondarenko, 2020). Money laundering in the field of public finance is the conversion of illegal funds (dirty) into legal net money. Money laundering is a complex, rather long financial process that allows the introduction of "dirty" funds into the legal economy and gives them the status of legally obtained (Dymchykov \& Repin, 2020).

Most shadow income money laundering schemes involve firms that are set up for a short period to implement specific schemes and are often used to launder the proceeds of crime by banks in underdeveloped countries (funds passed through their accounts or securities purchased from or through them). these institutions are almost impossible to trace). It is worth noting that banks act as assistants, advisers to fraudsters, as a rule, these are small banks of captive type. In connection with the hostilities in eastern Ukraine, fraudsters who use the volunteer movement to collect contributions have become more active. Most often, the use of international trade for money laundering is carried out through export transactions (non-refund of export foreign exchange earnings, understatement/overstatement of export prices, pseudo-exports, export on false documents); import operations (pseudo-import, inflated prices for imported goods, import on false documents); export-import and transit operations (carousel schemes, transit payments on fictitious imports and fictitious exports, transit of goods through the customs territory of the country) (Baranov, 2015).

Appropriation, embezzlement and misappropriation of public finances, abusing a position of authority

Analyzing the specified criminal offense, it should be noted that according to Art. 17 (Theft, misappropriation or other misappropriation of property by a public official) of the UN Convention against Corruption, signed by Ukraine on 31 October 2003 and ratified on 18 October 2006, each State Party "shall take such legislative and other measures as may be necessary to the criminalization of intentional theft, misappropriation or another misuse by a public official for the benefit of himself or another natural or legal person of any property, public or private funds, or securities, or any valuable object that is in the possession of this 
public official based on his official position" (United Nations, 2005). Article 191 of the Criminal Code of Ukraine provides for liability for three forms of committing a crime misappropriation, embezzlement, or seizure of property through abuse of office. They are characterized by the intentional illegal and gratuitous conversion of another's property to one's benefit or the benefit of another person. The subject of appropriation and embezzlement is only that other's property which was entrusted to the guilty person or was in his legal possession, ie such property which was in his lawful grounds and in respect of which he exercised authority to dispose of, manage, deliver, use or store, etc. In the case of misappropriation, these powers are used to turn the guilty person's property in their favor, and in case of embezzlement - in favor of others. In particular, it may be the alienation of property to others for consumption, as a gift or commodity, in exchange for other property, etc. (Politova, 2020).

In the case of misappropriation, embezzlement, and misappropriation of public finances, abusing a position of authority, there is a violation of two objects:

1) the obligatory basic - property relations (harm is caused to the owner - he becomes poorer as a result of committing this type of crime);

2) obligatory additional - relations that are formed regarding the distribution of material goods in society (there is an illegal enrichment of the guilty or other persons of his choice).

The absence of violation of both of these objects indicates that there is no criminal offense related to the illegal reversal of public finances in favor of individuals - there is another criminal offense or the act is not criminally illegal. The absence of a violation of an additional mandatory object makes it impossible to prove the existence of a selfish motive. The fact that the relationship that arises in connection with unjust enrichment is a mandatory additional object of the analyzed components of criminal offenses, can be seen even in the basic analysis at the household level. Figuratively saying, as a result of misappropriation, embezzlement, or seizure of public finances by an official abusing his official position, the owner, ie the state becomes poorer, and the guilty (or another person of his choice) gets rich. Possession of another's property, carried out through the exercise of power, can not be assessed as committed by an official abusing his position of authority. After all, the authority is to exercise the right within its competence to make demands, as well as to make decisions that are binding on legal entities and individuals, regardless of their departmental affiliation or competence. Of particular interest are the features of the essence of the analyzed violation and the responsibility of the participants of the collegial body. The authors believe that every member of a collegial body who has participated in the adoption of an illegal decision is liable if he or she influenced such a decision by voting (or in any other way). It should be emphasized the accuracy of the terminology - in the aspect of criminal law, we should not talk about "illegal decision-making by a collegial body", but about "illegal decision-making by a person acting as a member of a collegial body". Liability can occur only if the will of a member of the collegial body is recorded. Abuse of official position for misappropriation of public finances, their waste, or taking possession of them may be carried out not only individually, but also by a group of persons or persons acting as members of collegial bodies. Qualification of actions of a group of persons, in general, is not difficult - the responsibility comes taking into account the provisions of the Criminal Code of Ukraine on complicity in criminal offenses (Navrotsky, 2019), that is, depending on the role and type of accomplice, the form of complicity.

\section{Ways to combat corruption, the subject of which is public finance}

Modern theoretical developments in the conceptual problems of the fight against corruption do not address many current issues related to this negative social phenomenon. More towards, science develops general issues of combating corruption, the relationship of corruption with economic and organized crime, as well as private problems of the concept of official and corruption offenses, the classification of certain persons as officials, and so on.

At the same time, corruption has not been considered in the economic sciences, although at present there is a clear lack of legal and organizational regulation of this phenomenon as one of the areas of economic security.

In modern conditions, within the domestic legal system, a single branch of anti-corruption legislation has not been formed. The rules of law aimed at combating corruption are in different areas of law and are located in regulations of different levels. In particular, the Law of Ukraine 
"On Prevention of Corruption", the Criminal Code of Ukraine, the Code of Ukraine on Administrative Offenses and numerous bylaws of the Specialized Anti-Corruption Prosecutor's Office, the National Agency for Prevention of Corruption, the National Anti-Corruption Bureau and others.

In the author's opinion, general and special directions should be identified when determining the issue of combating corruption in the field of public finances. In particular, by the general direction, such methods of combating corruption as raising the legal anti-corruption culture of citizens, conducting public policy to involve various civil society institutions and the general population in the fight against corruption (a form of public control). The special approach should include combating corruption in the field of public procurement, combating money laundering in the field of public finances and combating corruption offenses.

The role of the community in combating corruption

It can be noted that the majority of citizens consider strong power as a recipe for the disease of corruption, believing that if it has the political will, can overcome this phenomenon together. At the same time, hoping for a strong state, many do not consider their participation in the fight against corruption, not believing that through the institutions of civil society they can influence the situation (Yagodin, 2017). The results of numerous scientific and applied studies show that the state without the active participation of both citizens and civil society institutions, can not reduce the level of corruption, and it is hardly possible in principle. In the current situation, it is necessary to pursue state policy aimed at involving various institutions of civil society and the general population in the fight against corruption, to develop their activity. It is necessary to organize a full-fledged dialogue between the state and civil society, and the state, represented by its authorities, must cooperate with various institutions of civil society. public control is one of the most important anticorruption mechanisms, which can (and must) serve as a serious obstacle to dishonest officials. It should be aimed at ensuring the rule of law in the spheres of state and municipal administration, to reduce the possibility of making and implementing at various levels of government illegal decisions that cause serious harm to society and state security. Public control can be an effective mechanism in the fight against corruption only if there is a strong political will to fight corruption.

\section{Combating corrupt abuses of public finances in the field of public procurement}

To eliminate illegal actions by participants in tenders, the legislation of developed western countries of the world has established precautionary measures. The most explicit prohibition of collusion between participants in tenders is in Canadian law. Section 47 of the Competition Act of Canada explicitly prohibits bid-rigging, which is defined as pre-arranged bidding or refusal of some potential participants in tenders to bid. Fraud with applications is punishable by imprisonment for up to 5 years and/or a fine, the amount of which is determined by the court. Similarly, the problem of collusion between participants in tenders is solved in the legislation of the European Union. Article 85 of the 1957 Treaty of Rome defines as incompatible with the principle of the common market all agreements which are directly or indirectly connected with the fixing by market participants of selling prices, purchase prices, or other trading conditions. Penalties for breaches of Article 85 are set separately by EU member states (Church, 2000).

It should be noted that the introduction of eprocurement complicates, but does not completely rule out the possibility of corruption in public procurement. The experience of conducting e-procurement in other countries of the world indicates that bidders still have significant leverage to limit suppliers' access to the public procurement market, and participants - to coordinate proposals, ie conspiracy (Melnikov, 2013).

Composition of ways to prevent and actively combat corruption abuses

To achieve some positive and qualitative changes in the fight against corruption, a comprehensive system of ways to combat such a negative phenomenon is needed by state control bodies, local governments, and public control bodies, based on the goal that corruption is psychologically for its subjects. uncomfortable and economically unprofitable not to mention its danger.

Thus, in many European countries, the high social status of civil servants is determined by competitive salaries, quality pensions, free insurance, and several other benefits. That is, the 
fight against corruption in the official sphere should be carried out at the national level within the framework of a special state policy aimed at harmonization to improve the criminal procedure and operational - search legislation.

In the author's opinion, it would be appropriate to amend the criminal law, namely to remove soft punishments from the sanctions of anticorruption criminal law and to agree with the position of many scholars who propose to increase the lower limit of sanctions for corruption offenses.

In the author's opinion, it is important to note the fact that the question of the establishment and effective functioning of specialized commissions to combat this destructive phenomenon in the civil service, given the fact that all officials are special subjects of all criminal offenses of corruption, most researchers, unfortunately, bypasses and does not analyze their practical activities and relevant legislation. While the prevention of corruption is certainly the most effective way of prevention that can affect the level of corruption in the country. The influence of the social phenomenon by preventing its occurrence is possible only when the impact is comprehensive on both the causes and conditions of its occurrence. Most often, to influence the conditions (factors), for example, contributing to the conflict of interest in the work of civil servants, and thus prevent socially dangerous consequences of misdemeanors is much easier than eliminating the causes of the conflict with law enforcement.

As for the practical activities of commissions for compliance with the requirements for the conduct of civil servants and conflict of interest, the main difficulty is the construction of an adequate system for monitoring the effectiveness of these commissions in the structure of public authorities or based on public authorities. in Ukraine, in the structure of local governments. To fully assess the monitoring of the effectiveness of the criteria for the activities of the above-mentioned specialized commissions in public authorities in Ukraine, the following can be proposed:

1) to record the facts of the presence or absence of arguments recorded in the documented decisions of the profile commissions, as well as their members.

2) to record and analyze all changes in the dynamics of the percentage of corruption offenses in different areas of state and municipal government.
3) public experts from among the representatives of the scientific community should occupy their niche in the specialized commissions for combating corruption and resolving conflicts of interest.

Reducing the level of other criminological indicators of corruption, applying only measures of criminal law influence, without the coordinated work of all elements of the structure of public power of the state is not an achievable task.

\section{Countering money laundering in public finance}

Today, the legal framework governing antimoney laundering activities is international law, such as the Council Convention on Laundering, Search, Seizure, and Confiscation of the Proceeds from Crime (Strasbourg, 8 November 1990), the Council Convention Of Europe on Money Laundering, Search and Confiscation of the Proceeds from Crime and on the Financing of Terrorism (Council of Europe, 2005) (Rosfinmonitoring, 2019).

The process of money laundering, like any other, has its own structure. The three-phase model is the most common, it includes three main stages that fully characterize the process of money laundering.

1. At the first stage there is a transfer of cash to any account. The persons or firms to whose account the transfer is made are fictitious, they may be acquaintances, and more often relatives of the offender. All these people are intermediaries in the commission of a crime and their main task is to create a personal bank account. Today it is important to transfer income to virtual assets, ie cryptocurrency. Money laundering using virtual means of payment makes it difficult to identify those who use them, as such means of payment as cryptocurrency position themselves as anonymous and maintain the confidentiality of the owner. The most accurate definition of cryptocurrency is proposed by Dumchikov M., Kononenko N., Batsenko L., Halenin, R. \& Hlushchenko N., emphasizing that cryptocurrency should be defined as a digital currency (virtual, without physical form), the creation and control of which is based on cryptographic methods, which is fully decentralized, which guarantees the correctness of transactions in the system, including the absence of the ability to influence transactions of participants in the 
cryptosystem (Dumchikov, M., Kononenko, N., Batsenko, L., Halenin, R., \& Hlushchenko, 2020).

2. At the next stage, criminals are involved in the distribution of cash. This becomes possible by acquiring assets that can be both financial and real. In the presence of a large number of fictitious persons, whose funds are involved, criminals can carry out a large number of small transactions, thereby returning to circulation most of all money.

3. At this stage, the integration of the entire money supply. It is characterized by the fact that previously legalized funds can be easily invested by criminals in absolutely any industry (Mezentsev \& Mezentseva, 2017).

Liability for money laundering occurs only if it has been proven that these funds were obtained by criminal means and this is often difficult to do, which is why you need to know the above stages and signs.

Thus, it should be said that the fight against criminal offenses of this essence requires effective mechanisms to combat money laundering. The inability to use the proceeds in this way will mean that criminal organizations will no longer be able to carry out illegal activities. To effectively combat legalization, it is necessary to know the stages and signs of the process given in the article, as well as the probable ways of its implementation.

\section{Conclusions}

Summarizing the above, the authors would like to emphasize that despite the democratic and legal aspirations of Ukraine, today this state is still one of the most corrupt. Abuses in the field of public finance are especially destructive, as they reduce the economic potential of the state, the financial well-being of the population and create a negative image for Ukraine in the international arena. Based on the analysis of statistical materials of criminal proceedings, the authors identified the most common forms of corruption, the subject of which is public finance: abuse in public procurement, legalization of income in public finance and misappropriation, embezzlement, and misappropriation of public finances, abuse of office. Besides, given the level of legislative regulation, legal awareness, legal culture, and education of the population of Ukraine, it is proposed to combat corruption offenses, the subject of which is public finance in two main areas: general and special. In particular, the general direction should include such ways to combat corruption as improving the legal anticorruption culture of citizens, public policy to involve various institutions of civil society, and the general population in the fight against corruption (a form of control by society). The special direction should include combating corruption in the field of public procurement, combating money laundering in the field of public finances, and combating corruption offenses more than or abusing of official position.

\section{Bibliographicreferences}

Akimov, O.O. (2014). Psychological aspects of manifestations of corruption in public administration. Public administration: theory and practice, № 1, 181-188.

Altsyvanovych, O.V., \& Tsymbalenko, Ya.Yu. (2018). Theoretical and categorical analysis of the concept of public procurement and corruption risks in their implementation in Ukraine. Aspects of public administration, № 9, pp. 92-103. Recovered

from: http://nbuv.gov.ua/UJRN/aplup_2018_6_9_12. Baranov, R.O. (2015). Modern schemes of money laundering in the world and in Ukraine. Aspects of public administration, № 7-8, 62-69. Recovered from http://nbuv.gov.ua/UJRN/aplup_2015_7-8_10. Bondarenko, O., Reznik, O., Yevgen, G., Andriichenko, N., \& Stohova, O. (2020). Participation of Ukraine in International Cooperation against Corruption. Amazonia Investiga, 9(29), 407-416 https://doi.org/10.34069/AI/2020.29.05.45

Bös, D. (2003). Introduction: Public versus Private Sectors in Public Finance - Selected Papers from the 58th Congress of the International Institute of Public Finance. International Tax and Public Finance 10, 313-315

https://doi.org/10.1023/A:1024672221561

Carlin, M. I. (2015). Local payments in the system of public finance of Ukraine. Scientific notes of the National University "Ostroh Academy", Vol. 28, 280-286.

Chen, A.H., \& Siems, T.F (2004). The effects of terrorism on global capital markets. European Journal of Political Economy, 20(2), pp. 349-366.

Church, J. R. (2000). Industrial organization: A strategic approach. Calgary : McGraw Hill.

Council of Europe (2005). Council of Europe Convention on Laundering, Search, Seizure and Confiscation of the Proceeds from Crime and on the Financing of Terrorism, No. 198. Warsaw, 
16.V.2005. Recovered from https://rm.coe.int/168008371f

Dumchikov, M., Kononenko, N., Batsenko, L., Halenin, R., \& Hlushchenko, N. (2020). Issues of regulating cryptocurrency and control over its turnover: international experience. Amazonia Investiga, $\quad 9(31), \quad$ 10-20. https://doi.org/10.34069/AI/2020.31.07.1

Dymchykov, M. O., \& Repin, D. A. (2020). Legalization of Proceeds of Crime Through Virtual Currency (Crypto Currency): Criminological and Criminal Aspect. Journal of Eastern European Law, 82, 32-37. http://doi.org/10.5281/zenodo.4665953

Ferenc, A. (2020). Procurement abuse: where to appeal? Transparency International Ukraine. Recovered from https://tiukraine.org/blogs/zlovzhyvannya-u-sferi-

zakupivel-kudy-zvertatysya/

Focsha, L. V. (2014). Public funds: concepts, features and legal nature. Scientific Bulletin of the International Humanities University, № 10-1, pp. 162-164.

Knack, S., \& Philip, K. (1997). Does Social Capital Have an Economic Payoff? A CrossCountry Investigation. The Quarterly Journal of Economics, 112(4), 1251-1288

Melnikov, O. S. (2013). Some ways to optimize e-procurement in Ukraine. Economy and State, № 9, 125-128.

Melnikov, O. S. (2016). Ways to combat corruption in the field of public procurement. Actual problems of public administration, № 1. 44-49. Recovered from http://nbuv.gov.ua/UJRN/apdy_2016_1_9.

Mezentsev, K., \& Mezentseva, N. (2017). View of cities from everywhere. Economic and social geography, Vol. 78, 66-69. Recovered from: http://nbuv.gov.ua/UJRN/esg_2017_78_12.

Rosfinmonitoring (2019). National assessment of risks of legalization (laundering) of proceeds from crime in 2017-2020. The main conclusions. Public version. Recovered from http://orgrsa.ru/upload/Ozenka_riskov.pdf

Politova, A. S. (2020). Appropriation, misappropriation of property or taking it by abuse of office as a corruption crime. Implementation of State Anti-Corruptionpolicies in the International Dimension Materials V International Scientific and Practical Conference (Kyiv, December 9-10, 2020) Recovered from http://elar.naiau.kiev.ua/bitstream/123456789/1 7881/1/\%D0\%9A\%D0\%BE\%D1\%80\%D1\%83 $\% \mathrm{D} 0 \% \mathrm{BF} \% \mathrm{D} 1 \% 86 \mathrm{i} \% \mathrm{D} 1 \% 8 \mathrm{~F} \% \mathrm{D} 0 \% \mathrm{~A} 7 \% \mathrm{D} 0$ $\% \mathrm{~B} 0 \% \mathrm{D} 1 \% 81 \% \mathrm{D} 1 \% 82 \% \mathrm{D} 0 \% \mathrm{~B} 8 \% \mathrm{D} 0 \% \mathrm{BD} \%$
D0\%B0_2_\%D0\%92\%D0\%95\%D0\%A0\%D0 $\% \mathrm{~A} 1 \% \mathrm{D} 0 \% \mathrm{~A} 2 \% \mathrm{D} 0 \% 9 \mathrm{~A} \% \mathrm{D} 0 \% 90 . \mathrm{pdf}$

Reznik, O. M. \& Bondarenko, O. S. (2020). Criminal-legal characteristic of objective signs of legalization (laundering) of proceeds from crime. Law and society, № 2, 133-139. DOI https://doi.org/10.32842/2078-3736/2020.2-3.21 Shkolnyk, I.O., \& Savchenko, T.G. (2018). Transparency of public finances - anticorruption: monograph: Sumy: Yaroslavna Publishing House.

Shrabani S., \& Kunal, S. (2021). The corruptiongrowth relationship: does the political regime matter? Journal of Institutional Economics, 17, 243-266. doi:10.1017/S1744137420000375

Shulga, T., Perepelytsia, M., Duravkin, P., \& Sharenko, M. (2019). International standards in the system of financial monitoring of Ukraine: issues of implementation. Amazonia Investiga, 8(19), 266-277. Retrieved from https://amazoniainvestiga.info/index.php/amazo nia/article/view/228

Taran, V. (2016). Honest budget. What it should be. Economic truth. Recovered from https://www.epravda.com.ua/columns/2016/03/ 25/586773/

United Nations (2005). United Nations Convention against Corruption. Recovered from https://www.unodc.org/documents/brussels/UN _Convention_Against_Corruption.pdf

Utkina, M. S. (2016). Principles of the financial system of Ukraine. Scientific Bulletin of Uzhgorod National University, 41(2), 78-81. Recovered from http://nbuv.gov.ua/UJRN/nvuzhpr_2016_41(2)_ -20

Utkina, M. S. (2020) Legal Status of Subjects of Primary and State Financial Monitoring in the Field of Combating Legalization Of Income Received. Legal Horizons, № 23. 73-77.

Winer, S. L. (2002). Introduction: The Role of Political Economy in the Theory and Practice of Public Finance - Selected Contributed Papers from the 57th Congress of the International Institute of Public Finance. International Tax and Public Finance 9, 327-329. https://doi.org/10.1023/A:1016512202522

Yagodin, R. S., \& Volkov, P. A. (2017) Anticorruption. Leningrad Law Journal, № 2(48). Recovered from https://cyberleninka.ru/article/n/protivodeystviekorruptsii

Yushko, S.V. (2018). Financial Scams And Abuse In The Field Of Public Procurement And Ways To Combat Them. Modern Problems of Economy and Entrepreneurship, № 21, 118-125. 